\title{
STRESSES IN A FEW WELDED AND RIVETED TANKS TESTED UNDER HYDROSTATIC PRESSURE.
}

\author{
By A. H. Stang and T. W. Greene.
}

\begin{abstract}
.
For the purpose of ascertaining the relative merits of riveted as compared with electric-welded tanks, four steel tanks, 4 feet in diameter and ro feet long, made of $\frac{5}{16}$-inch mild steel plates, were tested under hydrostatic pressure. Two of the tanks were butt welded, and one was lap welded, and the fourth was of the ordinary lap-riveted construction. The ends of the tanks were spherical, having a radius of 4 feet. Strain-gauge measurements were made at different pressures and the stress distribution and stress pressure relationship obtained. The results of the hydrostatic tests proved rather unsatisfactory for comparing the relative strengths of the different types, because of secondary failures.

For thin tanks, the measured stresses, based upon the two dimensional formulas for longitudinal as well as transverse stress in the tanks, are in close agreement with the design stresses computed by the common-pressure formulas, provided the former are not affected by secondary causes. Secondary stresses, which resulted in highstress intensity and produced failure in each case, were caused by (a) faulty design of the attachment of the spherical end to the cylindrical shell, $(b)$ nonconformity of the shell to an accurate circular section, and (c) discontinuities in the shell for the manhole and fittings.
\end{abstract}

\section{CONTENTS.}

Page.

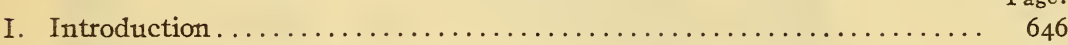

II. Description of the tanks. . . . . . . . . . . $6{ }_{4} 6$

I. General construction and workmanship................ 646

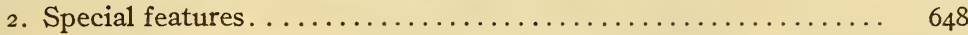

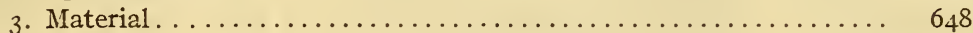

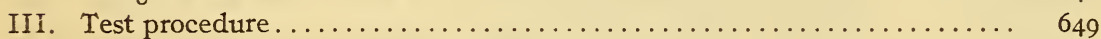

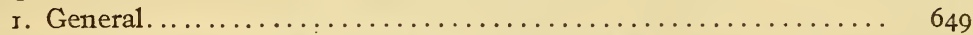

2. Location and designation of strain-gauge lines. . . . . . . . . . . 649

3. Deformation and strain-gauge measurements............. 649

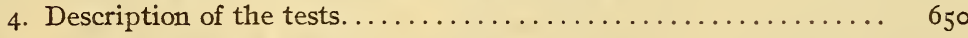

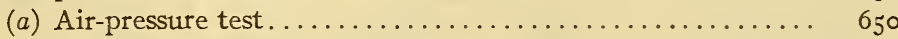

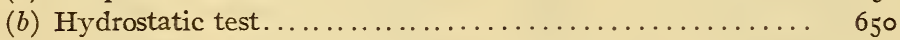

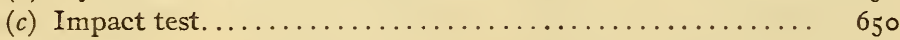

IV. Theoretical stresses. . . . . . . . . . . . . . . . . . . . . . $6_{50}$

I. Stress and strain in the cylindrical shell .................. $6_{50}$

2. Stress and strain in the spherical ends.................... $6_{5}$ I

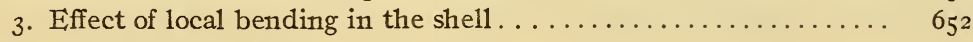

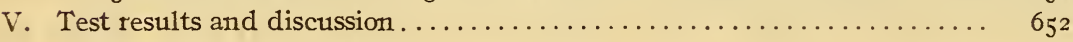

I. Method of presentation of test data ................ $6_{52}^{2}$ 
V. Test resuits and discussion-Continued.

2. Stresses in the shell

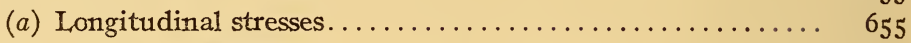

(b) Transverse stresses......................... $6_{56}$

(c) Diagonal stresses........................... 658

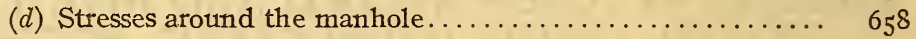

(e) Deformation of the shell...................... 659

3. Stresses in the end ............................. 659

4. Deformation of the ends and its effect upon the portions of the shell and end adjacent to their junction................. 66I

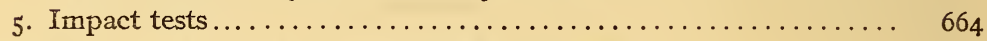

6. Failure of the tanks under hydrostatic pressure............ 664

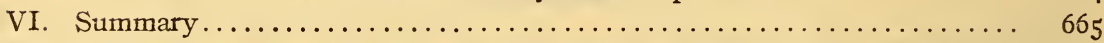

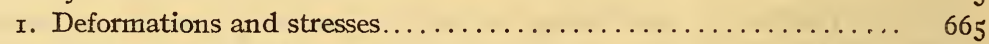

2. Mechanical details and recommendations.............. 666

\section{INTRODUCTION.}

Oxyacetylene welding and electric-arc welding have constantly found new fields of application. Among them has been the construction of tanks, pipe lines, and penstocks. Up to the present time, the larger number of pipe lines and penstocks of steel has been of riveted construction. For the purpose of ascertaining the relative merits of riveted as compared with welded pipes, the Riter-Conley Co., a subsidiary of the McClintic Marshall Co., designed and constructed four steel tanks for test, as this seemed to be the most convenient form in which to test the desired penstock construction. The tests also offered an opportunity for studying the stress distribution in the tanks subjected to internal pressure.

\section{DESCRIPTION OF THE TANKS.}

\section{GENERAL CONSTRUCTION AND WORKMANSHIP.}

Four tanks were tested. Two of them (Nos. 9 and Io) were butt welded, one (No. II) was lap welded, and the fourth (No. I2) was of the usual lap-riveted construction. Except where differences in construction made changes necessary, the tanks were identical. They had an internal diameter of 4 feet and a length of about ro feet 2 inches. The ends were spherical, being formed to an internal radius of 4 feet. The tanks were made of $\frac{5}{16}$-inch mildsteel plates, and were designed for a working pressure of 200 lbs./in. ${ }^{2}$ with a stress of $\mathrm{I} 6,000 \mathrm{lbs}$./in. ${ }^{2}$

Figure 2 shows the dimensions, general construction, location of the transverse and longitudinal joints, and of the tank fittings. The manhole saddle was welded both inside and out, while the flanges were welded to the shell on the outside and only "tack" welded in four places on the inside. 


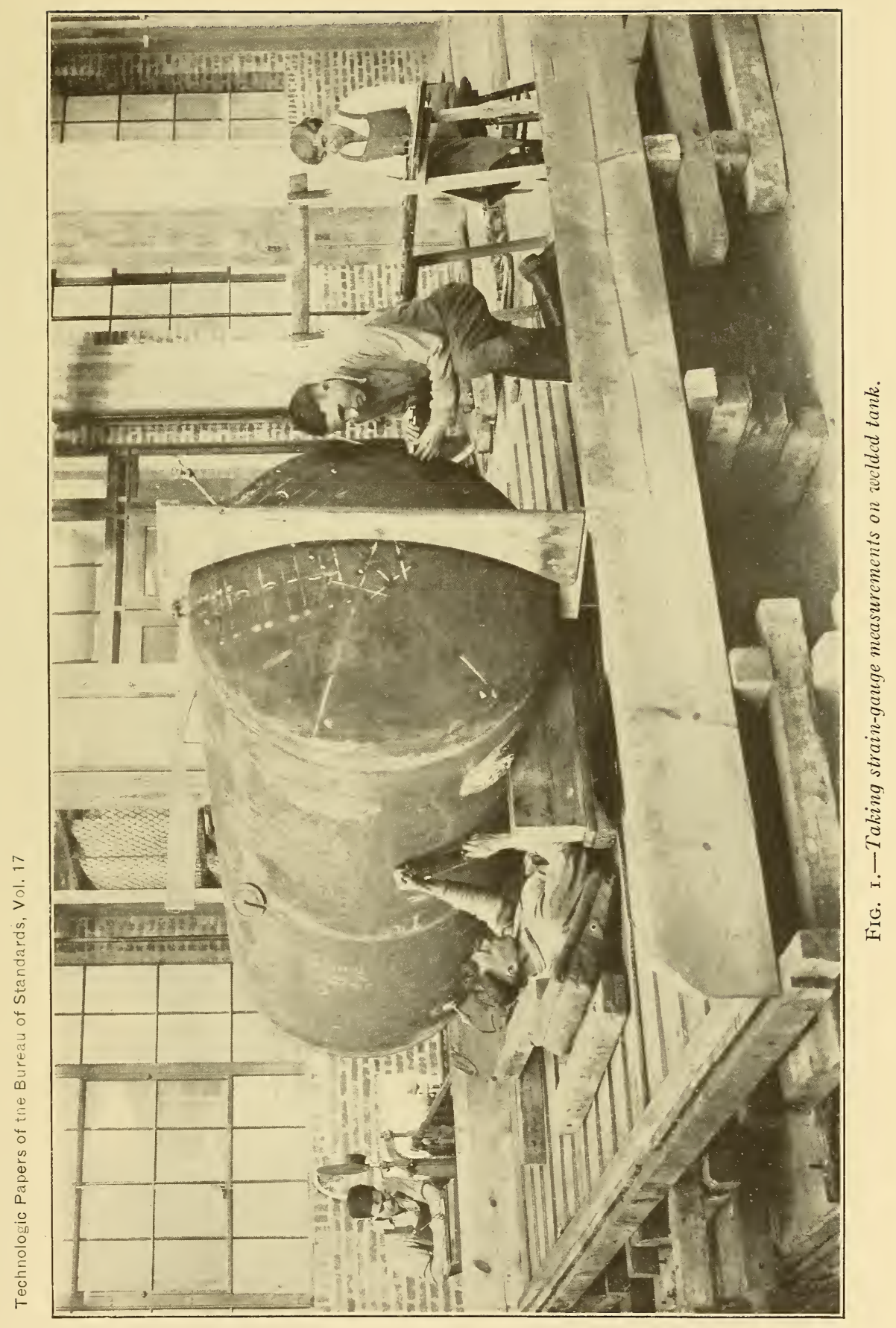


Technologic Papers of the Bureau of Standards, Vol. 17

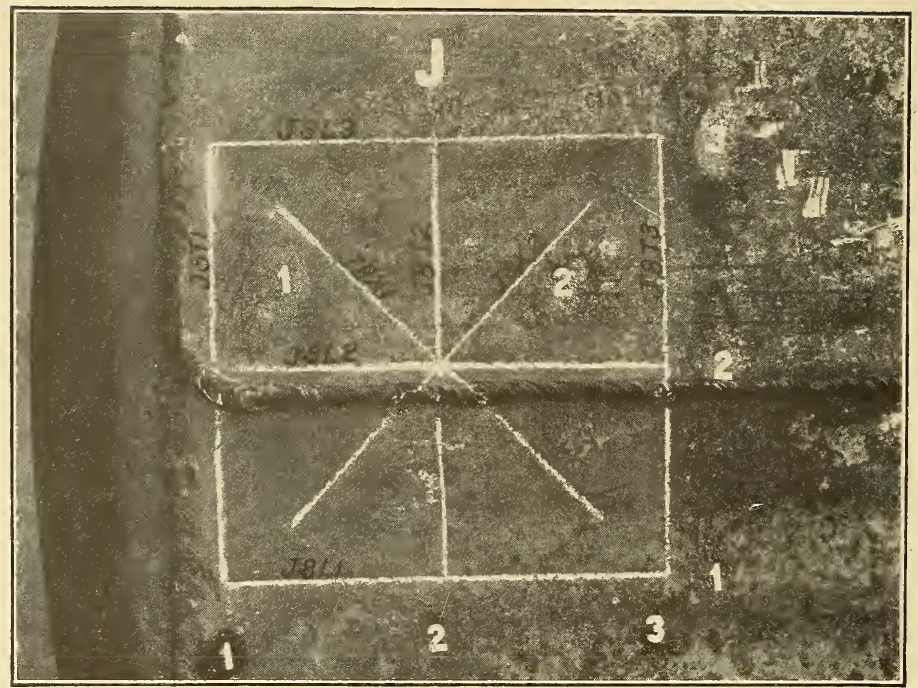

FIG. 3.-"Square" group of strain-gauge lines on the shell.

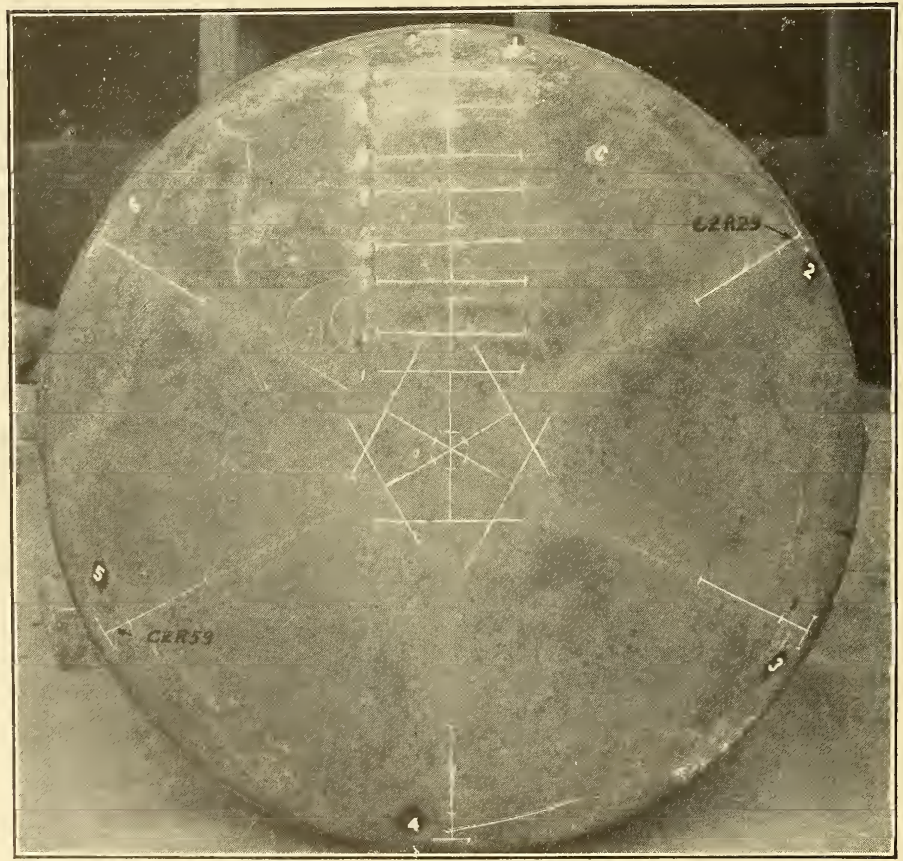

FIG. 4.-Location of gauge lines on the end of a tank. 

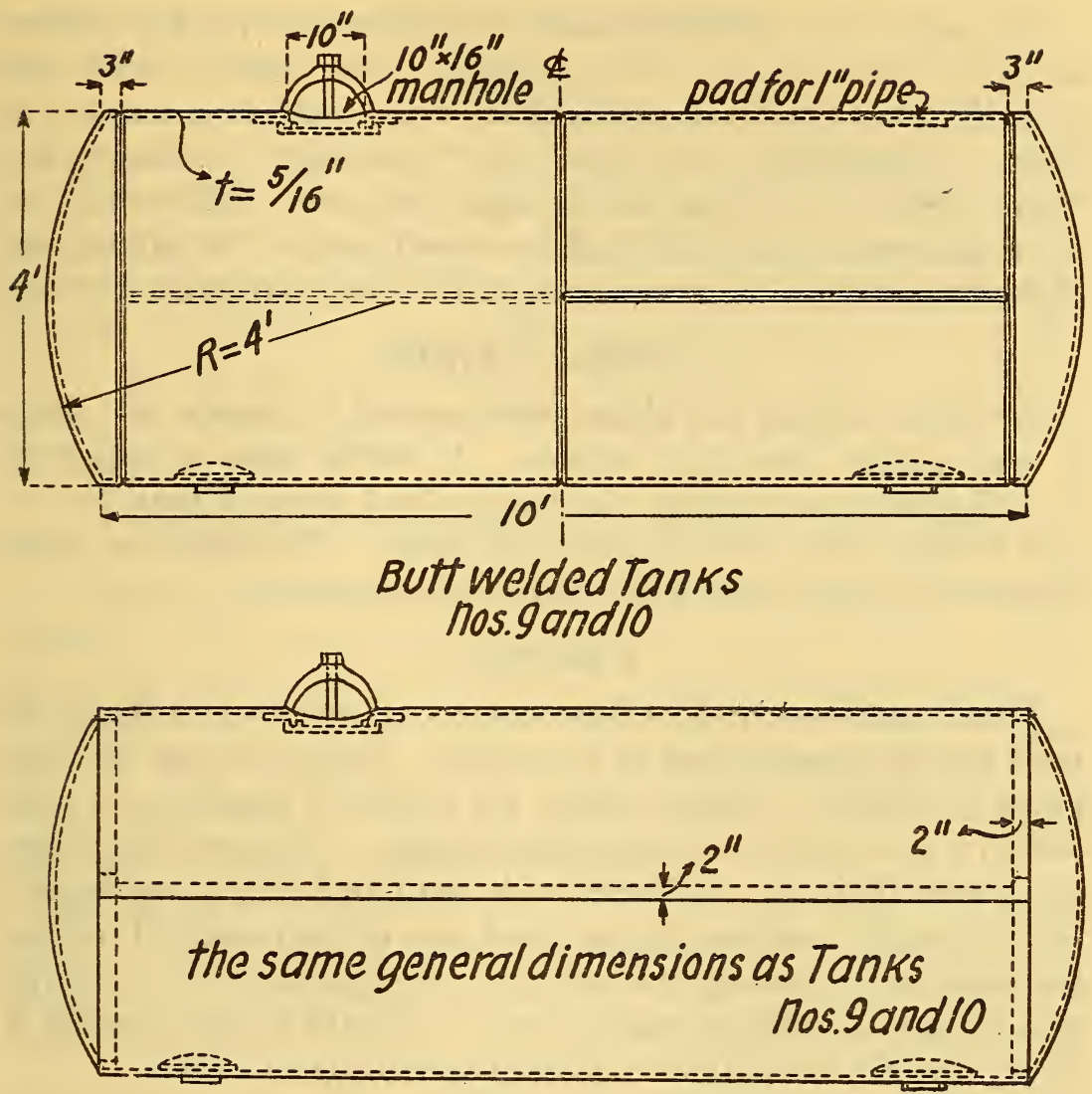

Lap welded Tank
Mo.ll

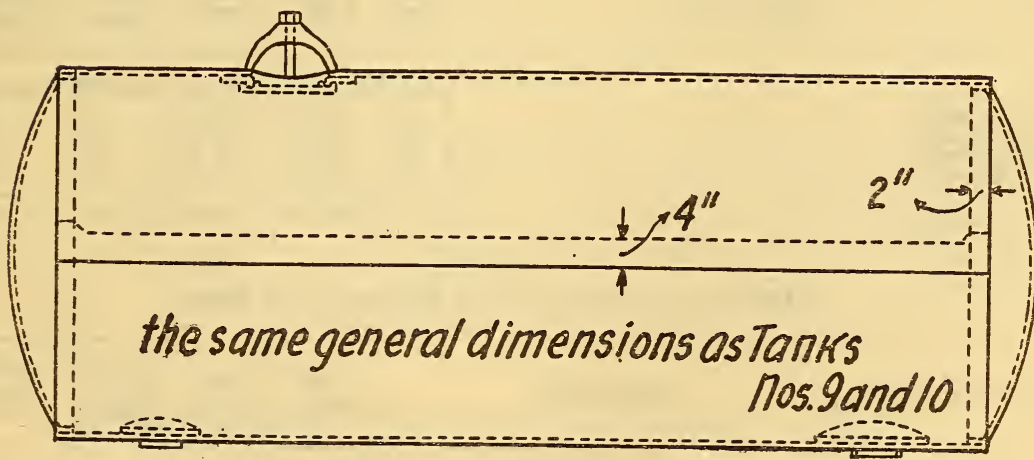

Riveted Tank Mo.12

FirG. 2.-The construction of tanks. 
The tanks were carefully made, the plates showing few depressions and the ends only minor refitting. The inside of butt-weld tank No. Io showed poor penetration of the weld in a number of places. Apparently, also, there were "cold shuts" or laps in the seams. Several of these leaked under pressure. This would not have occurred if the weld had been well made. In calking the riveted tank slight injury was done to the plates by undercutting.

\section{SPECIAL FEATURES.}

For butt welding the plates were scarfed to form a $90^{\circ}$ single $V$ and welded from the outside. A double row of staggered $5 / 8$-inch rivets was used on the longitudinal seam of tank No. I 2 and a single row on each of the end seams. The plate was bevel sheared at all the seams and calked on the outside.

\section{MATERIAL.}

Tensile tests were made of specimens cut from each of the plates used for the construction of the tanks. Results of the tests are given in Table $\mathrm{I}$. Table 2 shows the results of comparative tests made on two welded and one plain specimen. The specimens were all $\frac{5}{16}$ inch thick by $I \frac{1}{2}$ inches wide with an 8 -inch gauge length. For the welded coupons the sectional area of the unwelded portion was used in computing the strength. Comparative tests showed that the tensile strength was not greatly affected by the presence of welds, but the elongations of welded specimens was lower.

TABLE 1.-Tensile Test of Specimens Cut From Tank Plates.

\begin{tabular}{|c|c|c|c|c|c|}
\hline Tank number. & $\begin{array}{l}\text { Sam- } \\
\text { ples. }\end{array}$ & $\begin{array}{l}\text { Yield } \\
\text { point. }\end{array}$ & $\begin{array}{c}\text { Tensile } \\
\text { strength. }\end{array}$ & $\begin{array}{l}\text { Elonga- } \\
\text { tion in } 8 \\
\text { inches. }\end{array}$ & $\begin{array}{l}\text { Reduc- } \\
\text { tion of } \\
\text { area. }\end{array}$ \\
\hline $\begin{array}{l}9, \text { butt weld.... } \\
\text { 10, butt weld... } \\
11 \text {, lap weld.... } \\
\text { 12, riveted...... }\end{array}$ & \begin{tabular}{r|} 
No. \\
18 \\
18 \\
12 \\
18
\end{tabular} & $\begin{array}{r}\text { Lb. / } \text { in. }{ }^{2} \\
38,440 \\
38,210 \\
39,460 \\
37,660\end{array}$ & $\begin{array}{c}\text { Lb. } / \text { in }_{.}{ }^{2} \\
58,690 \\
60,840 \\
58760 \\
57,210\end{array}$ & $\begin{array}{r}\text { Per cent. } \\
30.2 \\
29.7 \\
30.5 \\
31.1\end{array}$ & $\begin{array}{r}\text { Per cent. } \\
54.1 \\
51.5 \\
50.7 \\
53.1\end{array}$ \\
\hline Average... & .. & 38,400 & 58,900 & 30.4 & 52.3 \\
\hline
\end{tabular}

TABLE 2.-Tensile Test of Welded Tank Plate.

\begin{tabular}{|c|c|c|c|c|c|}
\hline Specimen number. & Kind of weld. & $\begin{array}{l}\text { Yield } \\
\text { point. }\end{array}$ & $\begin{array}{c}\text { Tensile } \\
\text { strength. }\end{array}$ & $\begin{array}{l}\text { Elonga- } \\
\text { tion in } 8 \\
\text { inches. }\end{array}$ & $\begin{array}{l}\text { Reduc- } \\
\text { tion of } \\
\text { area. }\end{array}$ \\
\hline 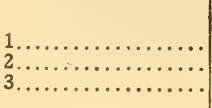 & 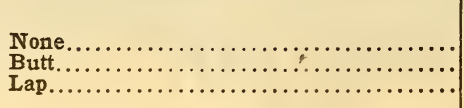 & $\begin{array}{r}\text { Lb. } / \text { in. } \\
33,900 \\
39,800 \\
40,200\end{array}$ & $\begin{array}{r}\text { Lb. } / \text { in. }^{2} \\
56,600 \\
57,750 \\
55,200\end{array}$ & $\begin{array}{r}\text { Per cent. } \\
32.5 \\
27.9 \\
\cdots\end{array}$ & $\begin{array}{r}\text { Per cent. } \\
56.7 \\
54.3 \\
\cdots\end{array}$ \\
\hline
\end{tabular}

NoTE.-Specimen No. 2 broke outside the weld; specimen No. 3 broke through the weld. 
III. TEST PROCEDURE.

\section{GENERAL.}

It was decided to measure the strains and deformations of the cylindrical shell and spherical end for $50 \mathrm{lbs} . /$ in. $^{2}$ increments of pressure until the tank failed. At a pressure of $300 \mathrm{lbs}$./in. ${ }^{2}, 50$ per cent in excess of the design pressure, an impact test was to be applied to all seams. The tanks were supported on two cradles cut to fit the shell and placed at the quarter points in order to reduce the shearing and bending stresses due to the weight of the water in the tank.

\section{LOCATION AND DESIGNATION OF STRAIN-GAUGE LINES.}

The gauge lines on the shell were located in groups, as shown in Figure 3. The gauge lengths for these lines were 8 inches. These gauge lines were used for the purpose of determining the variation of stress over the entire length of the tank, the effect of joints, and the effect of the ends on the adjoining portion of the shell. Other gauge lines were located around the manhole to determine the effect of discontinuities in the shell.

The location of gauge lines on the ends is shown in Figure 4. These were of both 8 and 2 inch lengths. Frequently 2-inch gauge lines were superimposed on the 8-inch in order to find the local variations of stress. The gauge lines on the end may be divided into two classes-radial and transverse. It was desired to study the variation of stress from the center to the periphery and along the joint with the shell. The gauge lines near the periphery were also used to study the effect of rapidly changing radius of curvature from the spherical end of radius 48 inches to the cylindrical shell of radius 24 inches.

The notation used for the gauge lines was as follows: The first letter indicates the group, followed by a figure showing the gauge length, either 2 or 8 inches; the second letter indicates the direction of the gauge line, $\mathrm{L}$ longitudinal, T transverse, $\mathrm{X}$ diagonal, $\mathrm{R}$ radial. The final figure specifies the particular gauge line of the group.

\section{DEFORMATION AND STRAIN-GAUGE MEASUREMENTS.}

The circumference of the shell at the center was measured with a steel tape reading to o.or foot, and by estimation to 0.00 I foot. To measure the deformation of the shell and of the end, two wooden frames were held by pivots to the shell as shown in Figure 
I. On these were reference lines from which measurements were made to the surface of the tank by means of a scale reading to o.or inch.

A 2 and an 8 inch strain gauge were used for measuring the deformations on the various gauge lines. Check readings were taken at each increment of pressure between a standard bar and the various gauge lines until the variation was less than 0.00005 inch per inch for the 2-inch gauge lines and 0.0000125 inch per inch for the 8-inch lines.

\section{DESCRIPTION OF THE TESTS.}

(a) AIR-Pressure Test.-Previous to the hydrostatic test the tanks were tested under an air pressure of $50 \mathrm{lbs}$./in. ${ }^{2}$, a soap solution being used to detect leaks. All the tanks, except tank No. Io, leaked in at least three or four places and were caulked with center punches.

(b) Hydrostatic Test.-After subjecting the tank to the airpressure test it was filled with water, care being taken that no air was trapped in the tank. The initial deformation and straingauge readings were then taken. To produce the desired pressure a hand pump, having a capacity of about $I \frac{1}{2}$ gallons per minute, was used. The pressure was read to the nearest $5 \mathrm{lbs}$./in. ${ }^{2}$ on a pressure gauge. The pressure was applied in increments of $50 \mathrm{lbs}$. $/$ in. ${ }^{2}$ and readings taken for each increment.

(c) IMPACT TEST.-The impact test was made at a pressure of $300 \mathrm{lbs}$. $/$ in. ${ }^{2}$ It consisted in striking alternately on each side of the seam with a ro-pound sledge hammer having a $2 \frac{1}{2}$-foot handle. Sharp blows were struck at the rate of about 60 per minute, causing a vibratory action of the plate adjacent to the weld.

\section{THEORETICAL STRESSES.}

\section{STRESS AND STRAIN IN THE CYLINDRICAL SHELL.}

According to the common approximate theory for thin cylinders under internal pressure the shell may be considered as subjected to three kinds of stresses-one transverse, tending to cause rupture along an element of the cylinder; another longitudinal, tending to cause rupture circumferentially; and a third radial, due to the difference of internal and external pressures. The radial stresses were negligible since the pressure differences were relatively small. 
The first two may be found from the common design formulas

$$
S_{\mathrm{T}}=\frac{p d}{2 t} \text { and } S_{\mathrm{L}}=\frac{p d}{4 t}
$$

in which $S$ is the stress, $p$ pressure, $d$ diameter, and $t$ the thickness of the shell. The stresses thus computed for these tanks for pressures up to $450 \mathrm{lbs}$./in. ${ }^{2}$ are given as "design" stresses in the various tables.

The transverse stress is twice the longitudinal, but this ratio does not exist between the strains because the principal stresses and principal strains are related by the following equations:

$$
\begin{aligned}
& e_{\mathrm{T}}=\frac{S_{\mathrm{T}}}{E}-\frac{S_{\mathrm{L}}+S_{\mathrm{R}}}{M E} \\
& e_{\mathrm{L}}=\frac{S_{\mathrm{L}}}{E}-\frac{S_{\mathrm{R}}+S_{\mathrm{T}}}{M E} \\
& e_{\mathrm{R}}=\frac{S_{\mathrm{R}}}{E}-\frac{S_{\mathrm{T}}+S_{\mathrm{L}}{ }^{1}}{M E}
\end{aligned}
$$

in which $e_{\mathrm{T}}, e_{\mathrm{I}}$, and $e_{\mathrm{R}}$ are the transverse, longitudinal, and radial strains, respectively, and $S_{\mathrm{T}}, S_{\mathrm{L}}$ and $S_{\mathrm{R}}$ the corresponding stresses. $E$ is Young's modulus and $I / M$ is Poisson's ratio. Assuming that $S_{R}$ is zero and $I / M=I / 3$, and expressing the stresses in terms of strains, there results

$$
\begin{aligned}
& S_{\mathrm{T}}=\frac{3 E}{8}\left(3 e_{\mathrm{T}}+e_{\mathrm{L}}\right) \\
& S_{\mathrm{L}}=\frac{3 E}{8}\left(3 e_{\mathrm{T}}+e_{\mathrm{T}}\right)
\end{aligned}
$$

The stresses in the diagonals may be found from the formula

$$
S_{\mathrm{x}}=\frac{3}{2} e_{\mathrm{x}} E
$$

where $e_{\mathrm{x}}$ is the average strain for two diagonal gauge lines which bisect each other at right angles.

\section{STRESS AND STRAIN IN THE SPHERICAL ENDS.}

The stress in the spherical end was computed by the design formula

$$
S=\frac{p R}{2 t}
$$

where $p$ is pressure in pounds per square inch, $R$ radius of the end in inches, and $t$ the thickness of the wall in inches.

${ }^{1}$ Morley's "Strength of materials" art. 19, p. 25. $55706^{\circ}-23-2$ 
The stresses in the spherical end may be found by the same two dimensional formulas as for the shell, viz,

$$
S=\frac{3}{2} e E
$$

since the stress and, therefore, the strain is theoretically independent of direction.

\section{EFFECT OF LOCAL BENDING IN THE SHELL.}

If a tank is not accurately formed, it will tend to become more nearly circular in section as the pressure is being increased. The resulting additional stresses may be found approximately by formula

$$
S=E i\left(\frac{\mathrm{I}}{R}-\frac{\mathrm{I}}{R_{\mathrm{O}}}\right)^{2}
$$

in which $E$ is the modulus of elasticity, $c$ the distance from the neutral axis to the extreme fiber, $R_{0}$ and $R$ initial and final radius of curvature. The computation shows that for the tanks tested a change in the radius of curvature of only 0.12 inch, which is one-half per cent of the design radius, would be sufficient to introduce an additional stress of about $\mathrm{I}, \mathrm{ooo} \mathrm{lbs}$./in. ${ }^{2}$

Rough measurements showed that the deviation from the average radius may be as large as $\mathrm{I}$ inch without being noticeable to the eye. A maximum deviation of 1.2 inches was found in one of the tanks. According to the above formula a change in radius of this amount would mean an additional stress of about Io,000 1bs./in. ${ }^{2}$ As the pressure tended to iron out these irregularities of the shell, a bending moment would be produced which would influence the magnitude of the stresses and might amount to several thousand $1 \mathrm{bs} . /$ in. $^{2}$

\section{TEST RESULTS AND DISCUSSION. \\ 1. METHOD OF PRESENTATION OF TEST DATA.}

The results of the tests are given in Tables 3 to ro, and shown graphically in Figures 5 to ro. These tables and curves do not cover all the observations made, but are considered as typical of the stress distribution in these tanks.

In order to express the relationship between pressure and deformation of the tank in terms generally employed in engineering practice, the measured strains in any direction have been multiplied by the value oi Young's modulus. This product $e E$ is defined as an "apparent" stress and denoted by the symbol $S$ '.

2Morley's "Strength of materials" art. x29, p. 376. 
In the curves, only the apparent stress values have been plotted, calculated by the formula

$$
S^{\prime}=e E
$$

where $S^{\prime}$ is the apparent stress, pounds per square inch, $e$ is the measured strain, inches per inch, and $E$ is the modulus of elasticity, a value of $29,000,000 \mathrm{lbs}$./in. ${ }^{2}$ having been used throughout. As the stresses in the tanks are not simple but are the resultant of essentially two principal stresses, it is not to be expected that the apparent stress obtained by this formula will check with the stress value which has been computed from the hydrostatic pressure. The apparent stresses will, however, show the variations of the strain on the various gauge lines, and give values from which the relative distribution of strain can be ascertained.

In all cases, except where the strains are of different sign, the two-dimensional formulas

$$
S_{\mathrm{X}}=\frac{3}{8} E\left(3 e_{\mathrm{X}}+e_{\mathrm{Y}}\right)
$$

will give higher values of stress than the formula $S^{\prime}=e E$. In those cases where the strain is approaching the yield point of the material this formula will indicate stresses which are higher than the yield point as determined by ordinary tensile test. This might be considered as an indication that the maximum strain rather than the maximum stress determined the yield point of the material. If so, the strains and not the stresses should be represented in the results. But such a method of presentation is inconvenient. An engineer is accustomed to think of a structural material in terms of stress and not of strain, the determination of which is usually considered as a means of finding the stress. Moreover the stresses calculated by the formula

$$
S_{\mathrm{X}}=\frac{3}{8} E\left(3 e_{\mathrm{X}}+e_{\mathrm{Y}}\right)
$$

might give an erroneous impression regarding the safety, which would appear to be lower than it is actually.

In order to reconcile these two requirements, to represent the stressed condition of the tanks in familiar terms and at the same time to give a correct idea of their safety it was decided to use the apparent stress in the graphs and tables. In some of the tables, however, the stresses have also been computed by the two dimensional formulas in order to compare these values with the design values. 

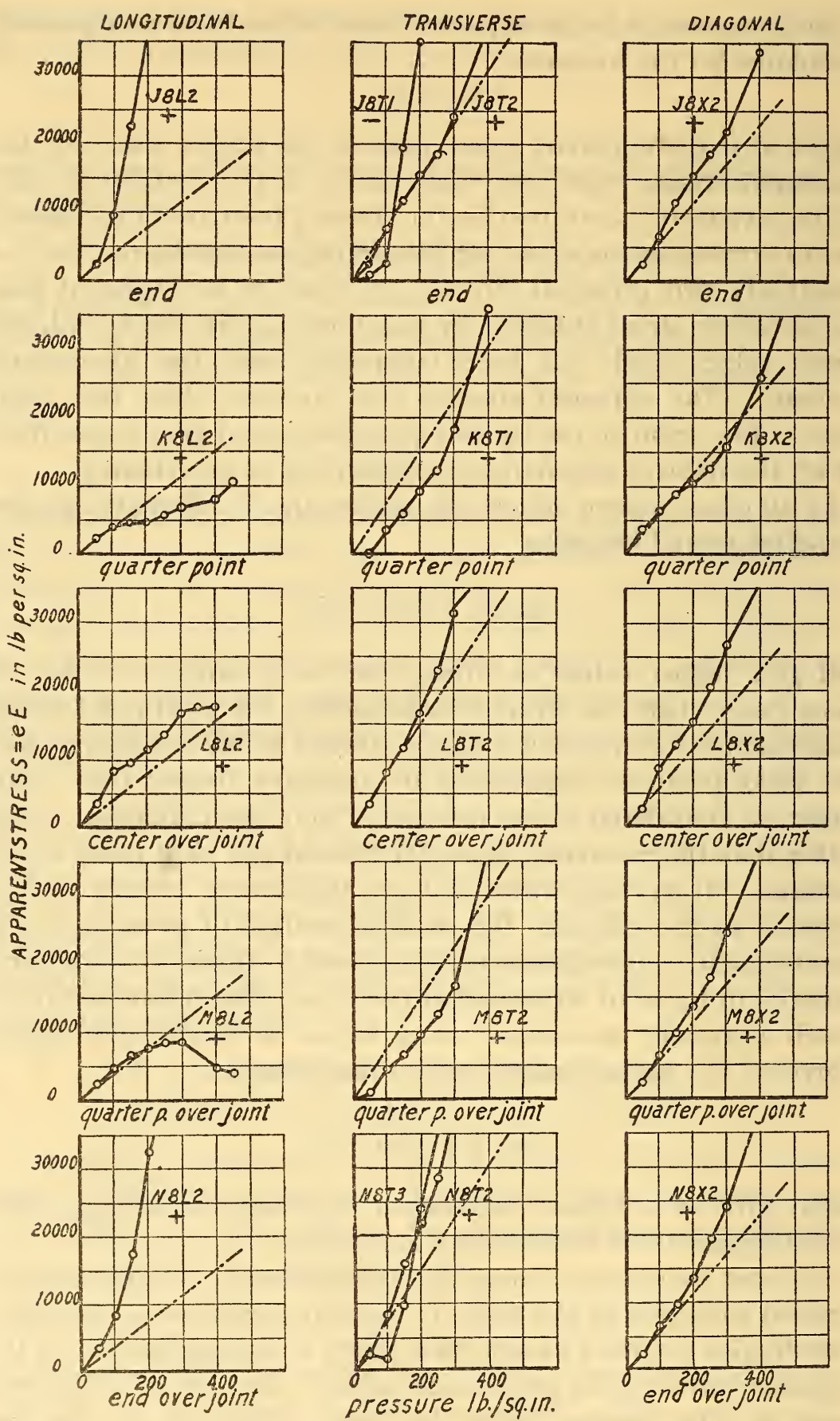

FIG. 5.-Typical pressure stress curves for gauge lines on the shell. (Tank No. 9.) + Tension. - Compression. _- Design stress (tension). 


\section{STRESSES IN THE SHELL.}

(a) Longitudinal Stresses.-Figure 5 shows typical pressurestress curves for gauge lines on the shell of tank No. 9. Figure 6 shows the variation of longitudinal stress along the tank for the groups of 8-inch gauge lengths located on the longitudinal seam. Values are plotted only for tanks Nos. 9 and II, since the 400 lbs./in. ${ }^{2}$ pressure was not reached on the other two tanks. In all cases the maximum stress was found in the gauge lines close to the ends, and in all cases this stress far exceeded its design value. This phenomenon was found to be due to the deformation of the shell at its junction with the spherical end, which will be discussed later.
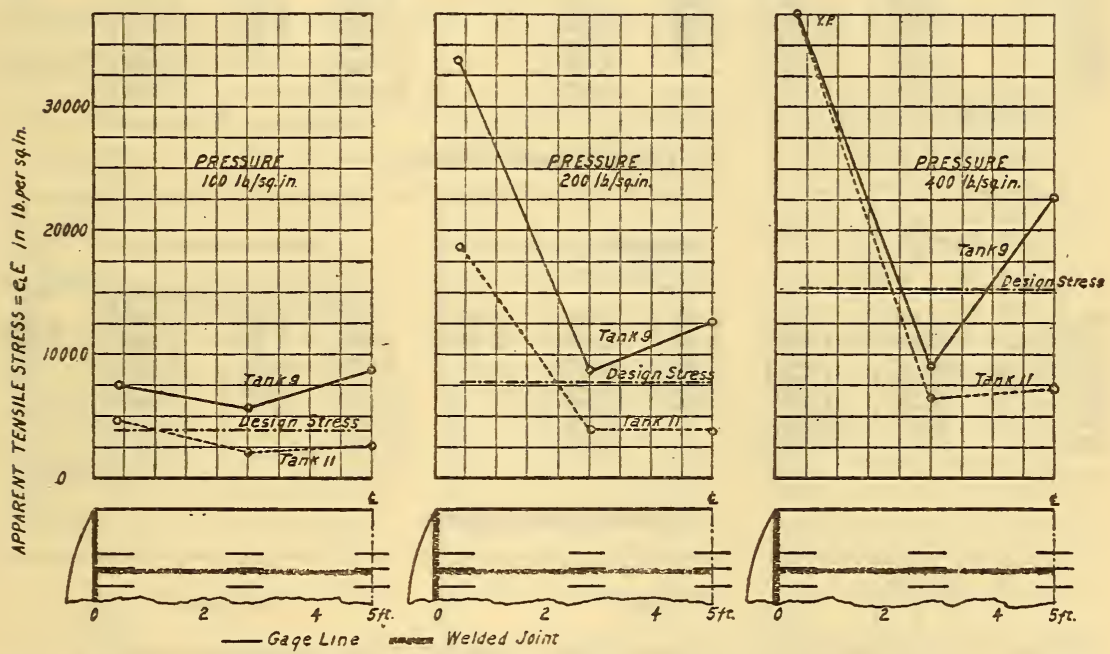

FIG. 6.-Variation of longitudinal stresses along the tank. Groups located on seams.

It will be noticed that for tank No. 9 the stresses at the center of the tank were much higher than at the quarter point. This was due to the presence of the transverse seam at the middle of the tank. For tank No. I I, which had no such transverse seam, the stress at the center was the same as at the quarter point.

The longitudinal stresses in the groups on the shell, which are not influenced by location near a seam, are given in Table $3(a)$. Both the apparent and two-dimensional measured stresses are given, together with the design stress for the various pressures. The apparent stresses are in all cases less than the two-dimensional stresses and in all but one case very much less than the design stress. The two-dimensional stresses were in closer agreement with the design stresses, the average ratio of the two-dimensional stresses for the four tanks to the design stresses being 0.99 . 
TABLE 3.-Stresses in Groups on the Shell Not Influenced by Location Near a Seam.

[All groups at quarter points.]

(a) LONGITUDINAL STRESS.

\begin{tabular}{|c|c|c|c|c|c|c|c|c|c|}
\hline \multirow{2}{*}{$\begin{array}{c}\text { Hydro- } \\
\text { static } \\
\text { pressure. }\end{array}$} & \multirow{2}{*}{$\begin{array}{l}\text { Design } \\
\text { stress. }\end{array}$} & \multicolumn{8}{|c|}{ Averaged measured stress. } \\
\hline & & $\begin{array}{l}\text { Tank 9, } \\
\text { group } \mathbf{K} .\end{array}$ & $\begin{array}{l}\text { Tank 10, } \\
\text { group G. }\end{array}$ & $\begin{array}{l}\text { Tank 11, } \\
\text { group G. }\end{array}$ & $\begin{array}{l}\text { Tank 12, } \\
\text { group G. }\end{array}$ & $\begin{array}{l}\text { Tank 9, } \\
\text { group } \mathrm{K} .\end{array}$ & $\begin{array}{l}\text { Tank 10, } \\
\text { group G. }\end{array}$ & $\begin{array}{l}\text { Tank 11, } \\
\text { group G. }\end{array}$ & $\begin{array}{l}\text { Tank 12, } \\
\text { group G. }\end{array}$ \\
\hline
\end{tabular}

Pounds per square inch.

\begin{tabular}{|c|c|c|c|c|c|c|c|c|c|}
\hline \multirow[b]{2}{*}{$\begin{array}{l}50 \ldots \ldots \ldots \\
100 \ldots \ldots . \\
150 \ldots \ldots \\
200 \ldots \ldots \\
250 \ldots \ldots \\
300 \ldots \ldots \\
400 \ldots \ldots \\
\end{array}$} & \multirow{2}{*}{$\begin{array}{r}S_{L}=\frac{P d}{4 t} \\
1,920 \\
3,840 \\
5,760 \\
7,680 \\
9,600 \\
11,520 \\
15,360\end{array}$} & \multicolumn{4}{|c|}{$S_{L}^{\prime}=e_{L} E$} & \multicolumn{4}{|c|}{$S_{\mathrm{L}}=8 / 8 E\left(3 e_{\mathrm{L}}+e_{\mathrm{T}}\right)$} \\
\hline & & $\begin{array}{l}1,400 \\
4,400 \\
4,400 \\
5,400 \\
6,300 \\
7,700 \\
8,300\end{array}$ & $\begin{array}{r}500 \\
1,100 \\
2,000 \\
2,500 \\
2,800 \\
\cdots \ldots . \cdots \\
\cdots \ldots . \cdots\end{array}$ & $\begin{array}{r}500 \\
400 \\
1,500 \\
1,600 \\
1,600 \\
2,400 \\
3,400\end{array}$ & 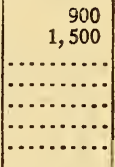 & $\begin{array}{r}1,700 \\
6,200 \\
7,100 \\
9,200 \\
11,300 \\
15,700 \\
23,000\end{array}$ & $\begin{array}{r}1,000 \\
2,400 \\
5,100 \\
6,300 \\
7,600 \\
\cdots \cdots \\
\cdots \cdots \\
\cdots \cdots\end{array}$ & $\begin{array}{r}1,800 \\
2,200 \\
4,800 \\
6,500 \\
7,400 \\
9,800 \\
15,000\end{array}$ & 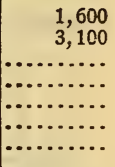 \\
\hline
\end{tabular}

(b) TRANSVERSE STRESS.

\begin{tabular}{|c|c|c|c|c|c|c|c|c|c|}
\hline \multirow[b]{2}{*}{$\begin{array}{l}50 \ldots \ldots . . \\
100 \ldots \ldots . \\
150 \ldots \ldots \\
200 \ldots \ldots \\
250 \ldots \ldots \\
300 \ldots \ldots \\
400 \ldots \ldots \\
\end{array}$} & \multirow{2}{*}{$\begin{array}{r}S_{T}=\frac{P d}{2 t} \\
3,840 \\
7,680 \\
11,520 \\
15,360 \\
19,200 \\
23,040 \\
30,720\end{array}$} & \multicolumn{4}{|c|}{$\therefore S^{\prime}{ }_{\mathrm{T}}=e_{\mathrm{T}} E$} & \multicolumn{4}{|c|}{$S_{\mathrm{T}}=8 / 8 E\left(3 e_{\mathrm{T}}+e_{\mathrm{L}}\right)$} \\
\hline & & $\begin{array}{r}0 \\
2,900 \\
5,300 \\
8,300 \\
11,200 \\
18,600 \\
36,300\end{array}$ & $\begin{array}{r}1,100 \\
3,100 \\
7,100 \\
8,800 \\
11,600 \\
\cdots \ldots . . . . \\
\cdots . . . . .\end{array}$ & $\begin{array}{r}3,400 \\
4,800 \\
8,500 \\
12,100 \\
14,700 \\
18,900 \\
29,600\end{array}$ & 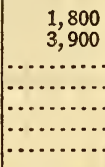 & $\begin{array}{r}600 \\
4,900 \\
7,600 \\
11,400 \\
15,100 \\
23,800 \\
43,900\end{array}$ & 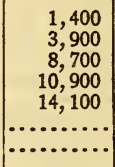 & $\begin{array}{r}4,000 \\
5,600 \\
10,100 \\
14,200 \\
17,200 \\
22,100 \\
34,600\end{array}$ & $\begin{array}{r}2,400 \\
4,900 \\
\cdots \cdots \\
\cdots \cdots \\
\cdots \cdots \\
\cdots \cdots \\
\cdots \cdots\end{array}$ \\
\hline
\end{tabular}

(c) DIAGONAI STRESS.

\begin{tabular}{|c|c|c|c|c|c|c|c|c|c|}
\hline \multirow[b]{2}{*}{$\begin{array}{l}50 \ldots \ldots \ldots \\
100 \ldots \ldots \\
150 \ldots \ldots \\
200 \ldots . . \\
250 \ldots \ldots \\
300 \ldots \ldots \\
400 \ldots \ldots\end{array}$} & \multirow{2}{*}{$\begin{array}{r}S_{\mathrm{X}}=\frac{S_{\mathrm{T}}+S_{\mathrm{L}}}{2} \\
2,880 \\
5,760 \\
8,640 \\
11,520 \\
14,400 \\
17,280 \\
23,040\end{array}$} & \multicolumn{4}{|c|}{$S^{\prime} x_{x}=e x E$} & \multicolumn{4}{|c|}{$S_{\mathrm{X}}=3 / 2 e_{\mathrm{X}} E$} \\
\hline & & $\begin{array}{r}4,100 \\
6,100 \\
8,400 \\
10,200 \\
12,300 \\
15,200 \\
24,900\end{array}$ & $\begin{array}{r}1,500 \\
3,200 \\
5,800 \\
6,400 \\
8,400 \\
\ldots \ldots \ldots \\
\cdots \ldots\end{array}$ & $\begin{array}{r}3,200 \\
3,200 \\
5,500 \\
7,500 \\
8,700 \\
11,300 \\
18,600\end{array}$ & 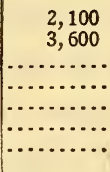 & $\begin{array}{r}6,100 \\
9,200 \\
12,600 \\
15,300 \\
18,400 \\
22,800 \\
37,400\end{array}$ & $\begin{array}{r}2,200 \\
4,800 \\
8,700 \\
9,600 \\
12,600 \\
\ldots . . . . . \\
\cdots . . . .\end{array}$ & $\begin{array}{r}4,800 \\
4,800 \\
8,300 \\
11,300 \\
13,100 \\
16,900 \\
27,800\end{array}$ & 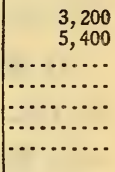 \\
\hline
\end{tabular}

(b). Transverse Stresses. - The transverse stresses along the tank for groups located on a longitudinal seam are shown in Figure 7. For all tanks, the extreme transverse gauge line, located close to the end, showed high compression. The reason for this high compression in these transverse gauge lines was the same as for the high tension in the corresponding longitudinal gauge lines, namely, the contraction of the diameter of the shell at the junction with spherical end. This effect is evidently only local and does not extend to any considerable distance toward the middle of the tank as the gauge lines 4 inches away showed tension. 
Transverse stresses in groups not influenced by the presence of a seam and located at the quarter point of the tank are given in Table $3(b)$. As with the longitudinal stresses, there is better agreement between the two dimensional and the design stresses than between the apparent and the design values. The two dimensional values, however, average about 25 per cent less than the design stresses at the lower pressures, but are in closer agreement at the higher pressures.

In order to determine the effect of the longitudinal seams on the stresses the transverse stresses in groups over a seam are given in Table 4. Comparing values in Table 4 with those in Table $3(b)$ it is seen that the stresses in lines over a seam were greater than in those not over a seam, the average increase being about 30 per cent.
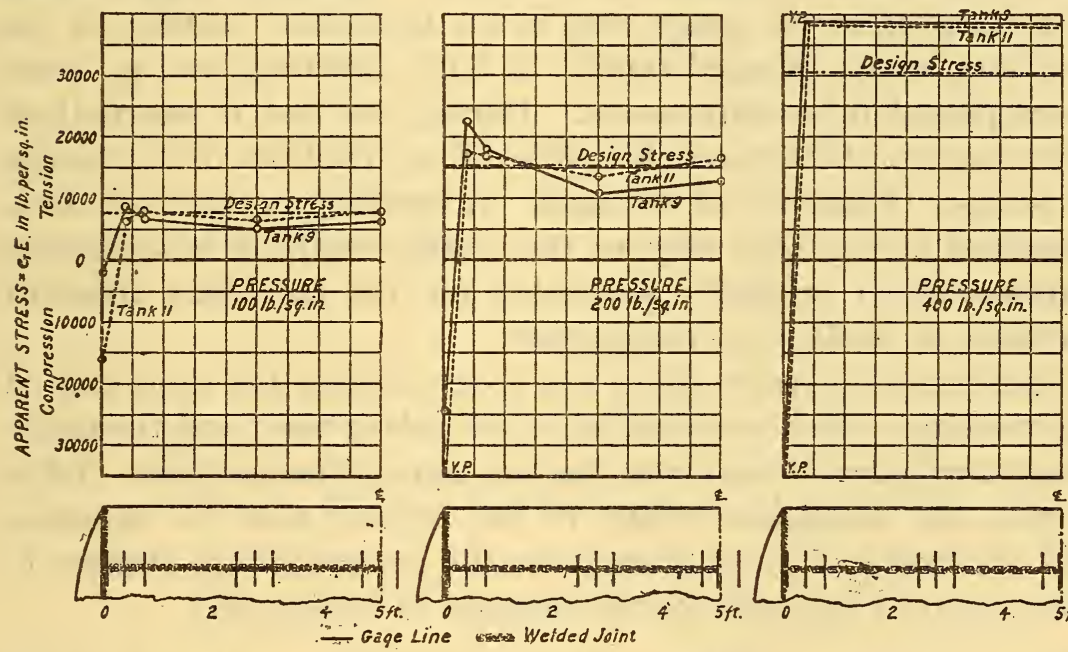

Fig. 7.-Variation of transverse stresses along the tank. Groups located on a seam

TABLE 4.-Transverse Stresses in Groups on the Shell Over a Seam. [All groups at quarter points.]

\begin{tabular}{|c|c|c|c|c|c|c|c|c|c|}
\hline \multirow{3}{*}{$\begin{array}{l}\text { Eydro- } \\
\text { static } \\
\text { pressure. }\end{array}$} & \multirow{3}{*}{$\begin{array}{c}\text { Design } \\
\text { stress } \\
S_{\mathrm{T}}=\frac{P d}{2 t}\end{array}$} & \multicolumn{8}{|c|}{ Averaged measured stress. } \\
\hline & & \multicolumn{4}{|c|}{$S_{\mathrm{T}^{\prime}}=e_{\mathrm{T}} E$} & \multicolumn{4}{|c|}{$S_{\mathrm{T}}=3 / 8 E\left(3 e_{\mathrm{T}}+e_{\mathrm{L}}\right)$} \\
\hline & & $\begin{array}{l}\text { Tank 9, } \\
\text { group M. }\end{array}$ & $\begin{array}{l}\text { Tank 10, } \\
\text { group M. }\end{array}$ & $\begin{array}{l}\text { Tauk 11, } \\
\text { group M. }\end{array}$ & $\begin{array}{l}\text { Tank } 12, \\
\text { group M. }\end{array}$ & $\begin{array}{c}\text { Tank 9, } \\
\text { group M. }\end{array}$ & $\begin{array}{l}\text { Tank 10, } \\
\text { group M. }\end{array}$ & $\begin{array}{l}\text { Tank 11, } \\
\text { group M. }\end{array}$ & $\begin{array}{l}\text { Tank 12, } \\
\text { group M. }\end{array}$ \\
\hline \multicolumn{10}{|c|}{ Pounds per square inch. } \\
\hline $\begin{array}{r}50 \ldots \ldots \\
100 \ldots \ldots \\
150 \ldots \ldots \\
200 \ldots \ldots \\
250 \ldots \ldots \\
300 \ldots \ldots \\
400 \ldots \ldots\end{array}$ & $\begin{array}{r}3,840 \\
7,680 \\
11,520 \\
15,360 \\
19,200 \\
23,040 \\
30,720\end{array}$ & $\begin{array}{l}1,100 \\
4,800 \\
4,400 \\
10,300 \\
14,700 \\
20,200 \\
Y . P .\end{array}$ & $\begin{array}{r}1,800 \\
4,300 \\
7,100 \\
9,600 \\
13,100 \\
\ldots \ldots \ldots . . . \\
\ldots \ldots . . .\end{array}$ & $\begin{array}{l}3,000 \\
6,200 \\
9,500 \\
13,000 \\
17,800 \\
26,600 \\
\text { Y.P. }\end{array}$ & $\begin{array}{r}4,000 \\
7,800 \\
\cdots \\
\cdots\end{array}$ & $\begin{array}{r}2,100 \\
7,400 \\
7,600 \\
14,600 \\
20,200 \\
25,900 \\
\mathbf{Y . P .}\end{array}$ & $\begin{array}{r}2,700 \\
6,400 \\
10,200 \\
13,500 \\
18,200 \\
\ldots \ldots \ldots \ldots \\
\ldots \ldots \ldots . . .\end{array}$ & $\begin{array}{r}3,800 \\
7,600 \\
11,700 \\
16,000 \\
21,700 \\
31,900 \\
Y . P .\end{array}$ & 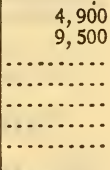 \\
\hline
\end{tabular}


(c) Diagonal, Stresses.-Diagonal stresses in groups not located on a seam are given in Table $3(c)$. The average ratio of the apparent to the design stresses is about 0.80 and of the twodimensional to the design value is I.r8. In Figure 5 are found typical pressure-stress curves for diagonal lines at different locations on tank No. 9.

(d) STRESSES ARound THE ManholE. - The observations of the effect of discontinuities on the distribution of stresses were made on the riveted tank No. I2. Due to the leaks, the pressure in it could not be raised above ${ }^{5}$ O $1 \mathrm{bs} . /$ in $^{2}{ }^{2}$ and the results are thus not complete.

The results of measurements were quite variable. The presence of the manhole introduced a considerable disturbing effect into the distribution of stresses in the shell. Generally high tension was observed in the gauge lines in the immediate vicinity of the manhole, which dropped rapidly in both directions and in some cases passed into compression. During the test it was noticed that the area of the manhole saddle did not conform to the change of contour of the rest of the tank. A bending moment was thus produced at the outer edge of the saddle, resulting in secondary stresses which probably accounted for the fact that adjacent portions of shell were compressed.

Maximum transverse stress was observed near the short axis of the manhole, which was parallel to the axis of tank, and the maximum longitudinal stress near the long axis of the manhole. Table 5 gives the maximum values of the stresses near the manhole and the ratios of these stresses to the corresponding stresses in other parts of the tank for the pressure of roo lbs./in. ${ }^{2}$

TABLE 5.-Comparison of Maximum Apparent Tensile Stresses Around the Manhole with Average Stresses at Other Points of Tank No. 12 for a Pressure of 100 lbs./in. ${ }^{2}$

\begin{tabular}{|c|c|c|c|c|}
\hline Gauge line. & 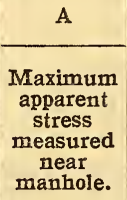 & $\begin{array}{l}\text { Ratio of A } \\
\text { to average } \\
\text { apparent } \\
\text { stress at } \\
\text { a quarter } \\
\text { point on } \\
\text { a plain } \\
\text { portion of } \\
\text { the shell. }\end{array}$ & $\begin{array}{c}\text { Ratio of } \mathbf{A} \\
\text { to average } \\
\text { apparent } \\
\text { stress at } \\
\text { a quarter } \\
\text { point over } \\
\text { a joint. }\end{array}$ & $\begin{array}{l}\text { Ratio of } \mathbf{A} \\
\text { to average } \\
\text { apparent } \\
\text { stress at } \\
\text { end of } \\
\text { shell. }\end{array}$ \\
\hline 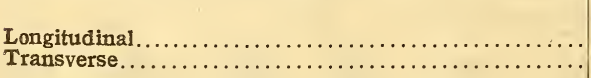 & $\begin{array}{r}\text { Lbs./in. }{ }^{2} \\
9,600 \\
15,700\end{array}$ & $\begin{array}{l}6.4 \\
4.0\end{array}$ & $\begin{array}{l}5.3 \\
2.0\end{array}$ & $\begin{array}{r}1.9 \\
-1.2\end{array}$ \\
\hline
\end{tabular}

1 For the gauge lines at the extreme end showing compression.

This table shows that for this tank the stresses around the manhole were the greatest, the effect of the manhole on the longitu- 

Technologic Papers of the Bureau of Standards, Vol. 17

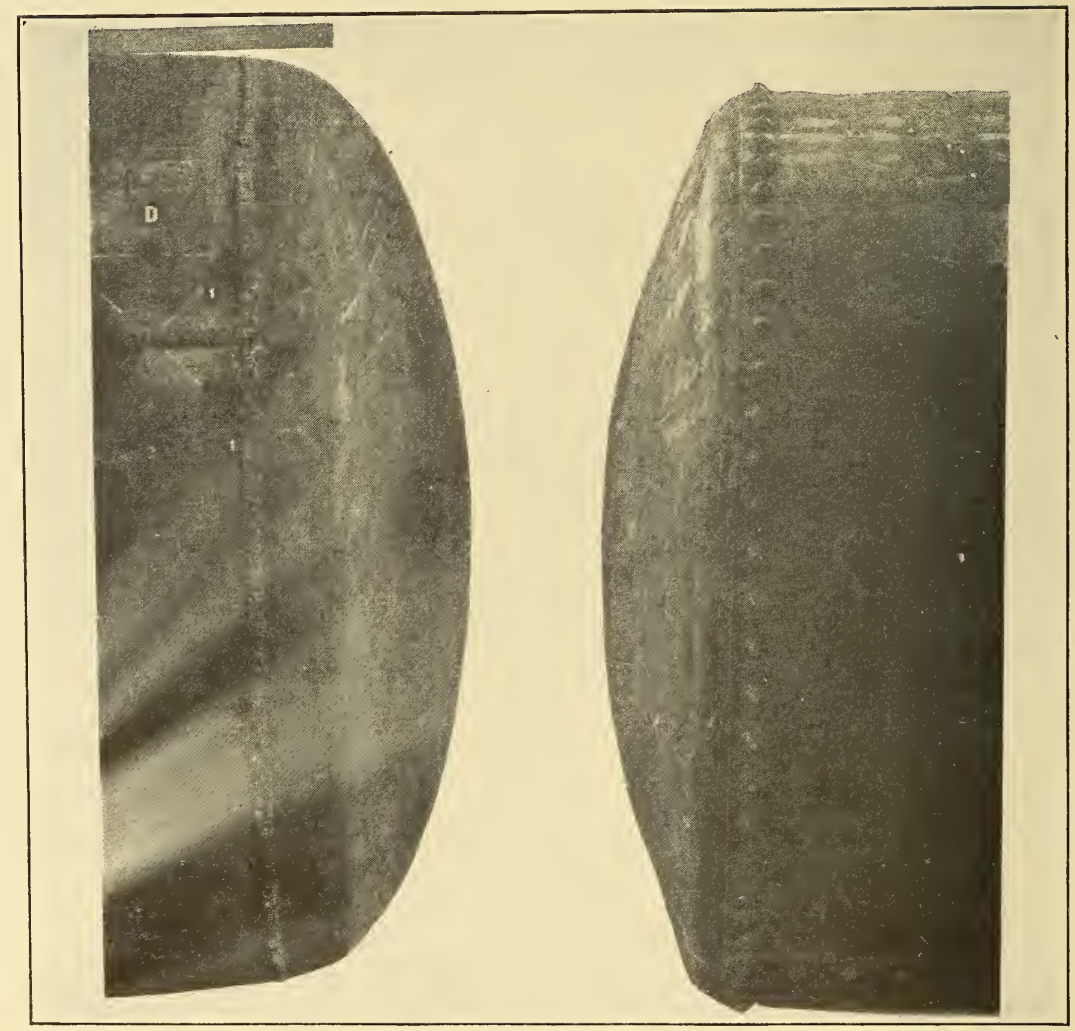

Fig. 9.-Deformation of the end and shell of tank No. 9, due to hydrostatic pressure, as compared with tank No. I2, which was not permanently deformed. 
dinal stresses being relatively greater than on transverse stresses. The last fact may be explained by the larger discontinuity at right angles to the longitudinal direction.

Reinforcing material at these points, carefully welded to the shell, would doubtless reduce the stresses and add to the strength of the tank.

(e) Deformation of The Shell.-For tanks Nos. 9, ro, and i I, at a pressure of $200 \mathrm{lbs}$. in. ${ }^{2}$, the average increase in circumference at the middle of the tank amounted to 0.076 inch, equivalent to an apparent transverse tensile stress of I 4,400 lbs./in. ${ }^{2}$ by the formula

$$
S^{\prime}{ }_{T}=e_{\mathrm{T}} E
$$
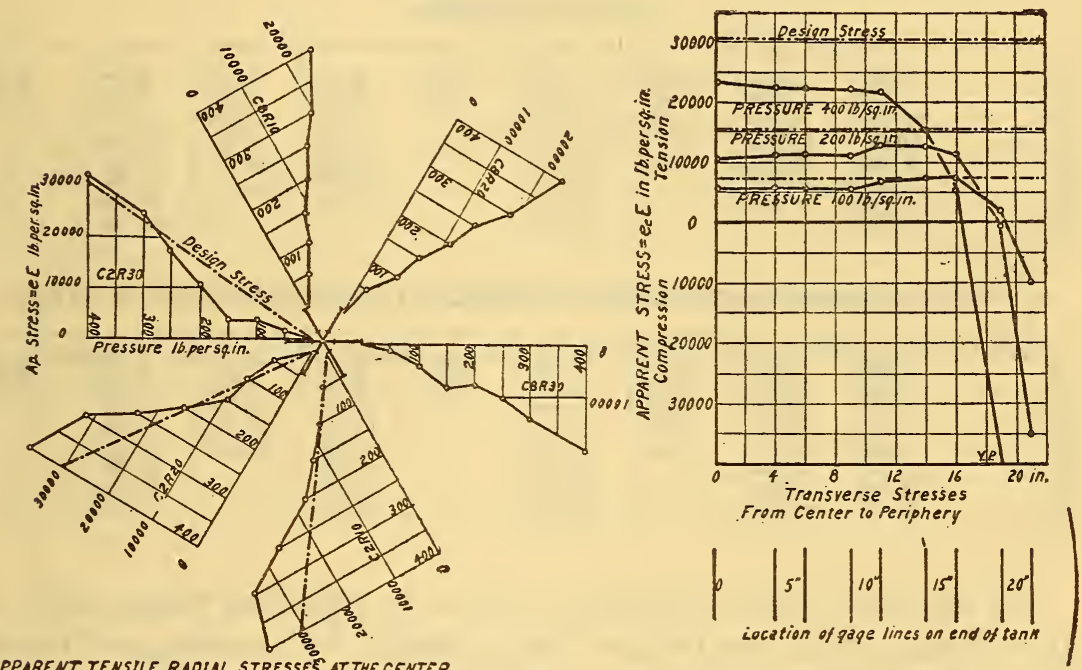

Fig. 8.-Stresses in the spherical end of tank No. 9.

or $17,300 \mathrm{lbs}$./in. ${ }^{2}$ by the two-dimensional formula. This agrees within the accuracy of the circumferential measurements with the design stress as given in Table $3(b)$.

At the end of the tank the diameter was contracted by the longitudinal deformation caused by the change in shape from the shell to the spherical ends, as shown in Figure 9.

\section{STRESSES IN THE END.}

Figure 8 shows the variation of stress for different pressures on 2 and 8 inch gauge lines located at the center of the spherical end of tank No. 9. In Table 6 the average stresses, both apparent and two-dimensional, for all the tanks at the center of the end are given, as well as the average stresses in six 8-inch gauge 
lines located 4 inches from the center. The apparent stresses are lower than the two-dimensional, the latter being in very close agreement with the design values for the entire range of pressure. The average ratio is in fact $\mathrm{r} . \mathrm{OI}$.

TABLE 6.-Average Stresses at Center of End of Tanks.

(a) AVERAGE STRESS IN THREE 8-INCH GAUGE LINES ACROSS CENTER OF END.

\begin{tabular}{|c|c|c|c|c|c|c|c|c|c|}
\hline \multirow{3}{*}{$\begin{array}{l}\text { Hydro- } \\
\text { static } \\
\text { pres- } \\
\text { sure. }\end{array}$} & \multirow{3}{*}{$\begin{array}{c}\text { Design } \\
\text { stress } \\
S=\frac{P R}{2 t .}\end{array}$} & \multicolumn{8}{|c|}{ Averaged measured stress. } \\
\hline & & \multicolumn{4}{|c|}{$S^{\prime}=e E$} & \multicolumn{4}{|c|}{$S={ }_{2}^{3} e_{\theta} E$} \\
\hline & & Tank 9. & Tank 10. & Tank 11. & Tank 12. & Tank9. & Tanik $10 . \mid$ & Tank 11. & Tank 12. \\
\hline
\end{tabular}

Pounds per square inch.

\begin{tabular}{|c|c|c|c|c|c|c|c|c|c|}
\hline 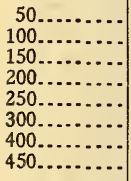 & $\begin{array}{r}3,840 \\
7,680 \\
-11,520 \\
15,360 \\
19,200 \\
23,040 \\
30,720 \\
34,560\end{array}$ & $\begin{array}{r}2,000 \\
5,500 \\
8,100 \\
10,400 \\
13,100 \\
17,400 \\
23,200 \\
\ldots \ldots \ldots . . .\end{array}$ & 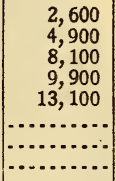 & $\begin{array}{r}2,300 \\
5,200 \\
7,500 \\
9,000 \\
12,300 \\
14,800 \\
20,900 \\
22,900\end{array}$ & 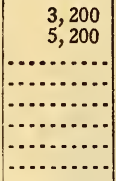 & $\begin{array}{r}3,100 \\
8,300 \\
12,200 \\
15,700 \\
19,600 \\
26,100 \\
34,800 \\
\ldots . . . . .\end{array}$ & 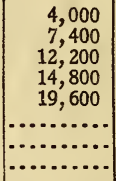 & $\begin{array}{r}3,500 \\
7,800 \\
11,300 \\
13,500 \\
18,500 \\
22,300 \\
31,300 \\
34,300\end{array}$ & 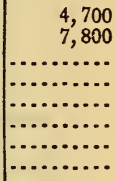 \\
\hline
\end{tabular}

(b) AVERAGE STRESS IN SIX 8-INCH GAUGE LINES, 4 INCHES FROM CENTER OF END.

\begin{tabular}{|c|c|c|c|c|c|c|c|c|c|}
\hline 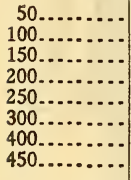 & $\begin{array}{r}3,840 \\
7,680 \\
11,520 \\
15,360 \\
19,200 \\
23,040 \\
30,720 \\
34,560\end{array}$ & $\begin{array}{r}2,000 \\
5,500 \\
7,000 \\
10,400 \\
12,800 \\
16,000 \\
21,200 \\
23,200\end{array}$ & 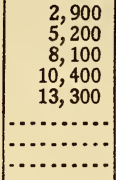 & $\begin{array}{r}2,300 \\
5,500 \\
8,100 \\
10,200 \\
13,100 \\
16,000 \\
21,500 \\
23,500\end{array}$ & 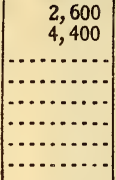 & $\begin{array}{r}3,100 \\
8,200 \\
10,400 \\
15,700 \\
19,100 \\
23,900 \\
31,700 \\
34,800\end{array}$ & 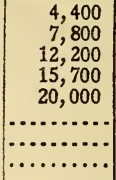 & $\begin{array}{r}3,500 \\
8,200 \\
12,200 \\
15,200 \\
19,500 \\
23,900 \\
32,200 \\
35,200\end{array}$ & 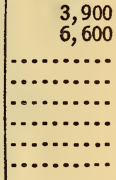 \\
\hline
\end{tabular}

As the ends were accurately formed to spherical shape, and as the strains at the center are least affected by secondary stresses a closer agreement for these measurements was to be expected than for measurements made at any other portions of the tank. These readings showed that in an accurately formed spherical shell under internal pressure the stresses were equal in all directions, and for thin tanks, such as these, the two-dimensional formula represents the actual stress-strain relation.

At the periphery of the end the transverse stresses passed rapidly into compression, reaching the yield point at very low pressures. Figure 8 shows the variation of the transverse stresses from the center to the periphery of the ends from measurements on 8-inch gauge lines on tank No. 9 . 
4. DEFORMATION OF THE ENDS AND ITS EFFECT UPON THE PORTIONS OF THE SHELL AND END ADJACENT TO THEIR JUNCTION.

At the junction of the spherical end and the cylindrical shell there was a marked deformation under hydrostatic pressure, as shown in Figure 9. Figure ro shows the radial measurements of this deformation plotted to an exaggerated scale. These measurements show that the greatest effect in deforming the tank was in the neighborhood of the junction and a minimum at the center. The center of the ends protruded to quite an extent,

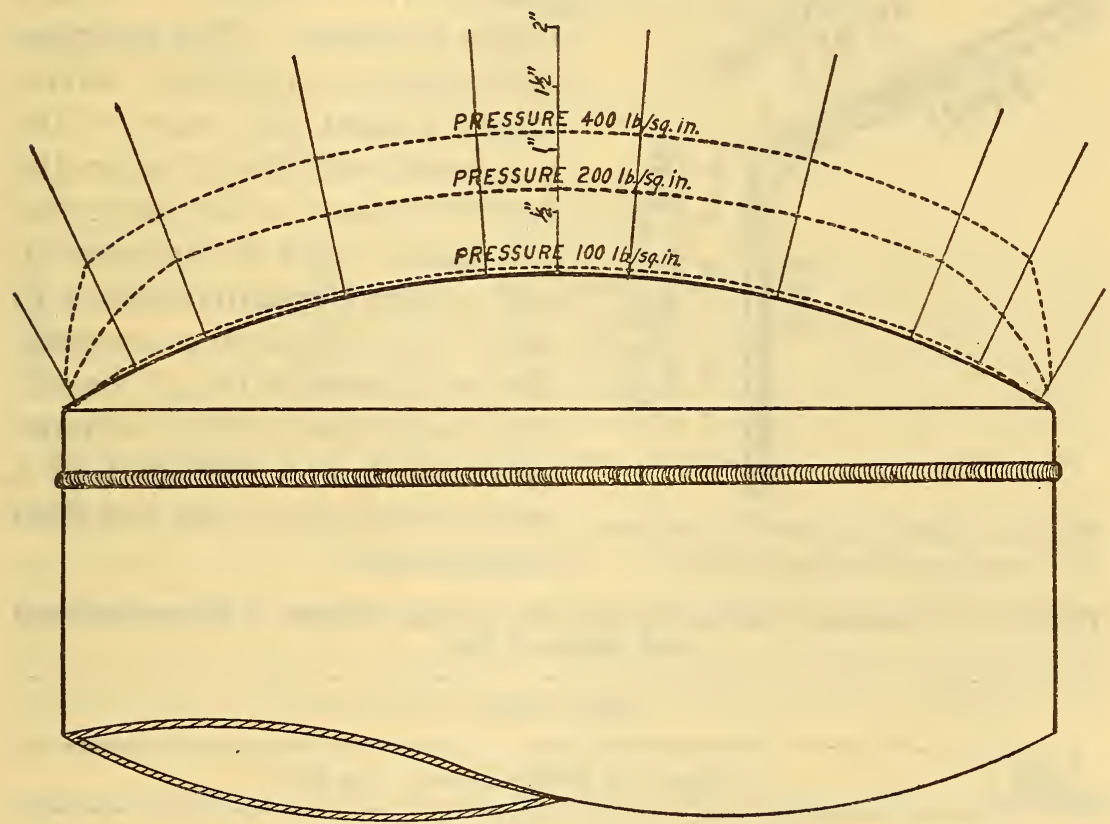

Fig. Io.-Radial deformation of spherical end of tank No. 9 plotted to an exaggerated scale.

although the radius of curvature did not appreciably change. Near the junction the change in form was very pronounced.

There is a sharp change of curvature where the spherical end joins the cylindrical shell. The forces which represent the action of the end on the shell are not directed along the elements of the cylinder, but at an angle to it, and this must result in the contraction of the adjoining portion of the shell and of the end itself. The result of this deformation was compression in the transverse direction in this portion of the tank with a resultant abnormal increase in the longitudinal and radial tensile stresses. 
In order to determine the magnitude of the transverse stresses adjacent to the junction, a special series of measurements was made on 2-inch gauge lines I inch apart on tank No. 9 located on the shell and end. The results of the measurements are given in Table 7. It will be seen that the yield point in compression had been reached at the very low pressure of $100 \mathrm{lbs}$./in. ${ }^{2}$, or less than one-half the working pressure, for those gauge lines nearest

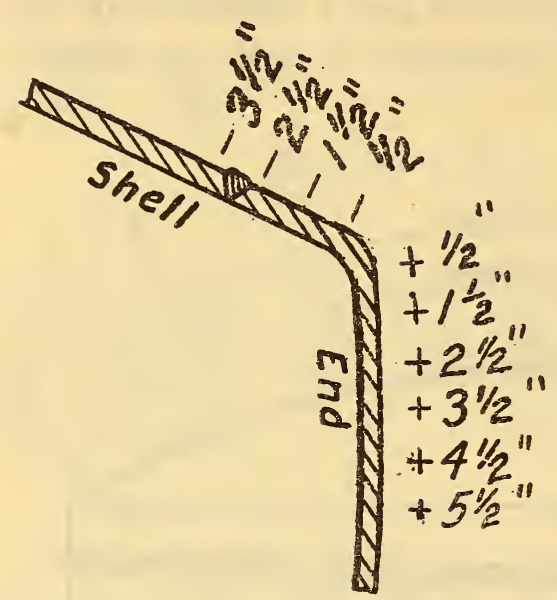

FIG. II.-Lacation of special 2-inch transverse gauge lines near junction. the junction. As the distance from the junction increased, the yield point was reached at slightly higher pressures. This compressive effect extended for several inches toward the center of the end, being sufficient to reduce the tensile stresses in the gauge line $5 \frac{1}{2}$ inches away to compression, and causing the material there to reach the yield point in compression at a pressure of $450 \mathrm{lbs}$./in. ${ }^{2}$ This compressive effect was more pronounced and extended to a greater distance on the end than on the shell.

TABLE 7.-Transverse Stresses in Tank No. 9 Near Junction of Cylindrical Shell and Spherical End.

\begin{tabular}{|c|c|c|c|c|c|c|c|c|c|c|}
\hline \multirow{3}{*}{$\begin{array}{l}\text { Hydro- } \\
\text { static } \\
\text { pressure. }\end{array}$} & \multicolumn{10}{|c|}{ Apparent stress $S^{\prime} \mathrm{T}=e_{\mathrm{T}} E$. } \\
\hline & \multicolumn{6}{|c|}{ Distance from junction (inches.) } & \multicolumn{4}{|c|}{ (See fig. 11.) } \\
\hline & $-3 \frac{1}{2}$ & $-2 \frac{1}{2}$ & $-1 \frac{1}{2}$ & $-\frac{1}{2}$ & $+\frac{1}{2}$ & $+I_{\frac{1}{2}}$ & $+2 \frac{1}{2}$ & $+3 \frac{1}{2}$ & $+4 \frac{1}{2}$ & $+5 \frac{1}{2}$ \\
\hline
\end{tabular}

Pounds per square inch.

\begin{tabular}{|c|c|c|c|c|c|c|c|c|c|c|}
\hline $\begin{array}{l}50 \ldots \ldots \ldots \\
100 \ldots \ldots \ldots \\
150 \ldots \ldots \\
200 \ldots \ldots \\
250 \ldots \ldots \\
300 \ldots \ldots \\
400 \ldots \ldots \\
450 \ldots \ldots\end{array}$ & $\begin{array}{r}+4,400 \\
+8,700 \\
+7,300 \\
0 \\
-5,200 \\
-4,800 \\
-26,100 \\
-29,000\end{array}$ & 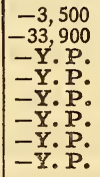 & 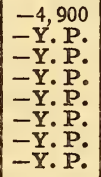 & 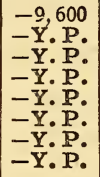 & $\begin{array}{l}-4,400 \\
-Y \cdot P \cdot \\
-Y \cdot P \cdot \\
-Y \cdot P \cdot \\
-Y \cdot P \cdot \\
-Y \cdot P \cdot \\
-Y \cdot P \cdot \\
-Y \cdot P\end{array}$ & $\begin{array}{l}-4,600 \\
-32,800 \\
-Y . P \\
-Y . P \\
-Y . P \\
-Y . P . \\
-Y . P . \\
-Y . P . \\
-Y . P .\end{array}$ & 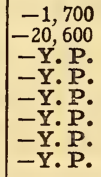 & $\begin{array}{l}-2,300 \\
-9,300 \\
-20,300 \\
-\mathbf{Y} . P . \\
-\mathbf{Y} \cdot \mathbf{P} . \\
-\mathbf{Y} \cdot \mathbf{P} . \\
-\mathbf{Y} \cdot \mathbf{P} . \\
-\mathbf{Y} . \mathbf{P} .\end{array}$ & $\begin{array}{r}+3,800 \\
0 \\
+600 \\
-13,100 \\
-36,300 \\
-\mathbf{Y} . \mathbf{P} . \\
-\mathbf{Y} . \mathbf{P} \\
-\mathbf{Y} . \mathbf{P} .\end{array}$ & $\begin{array}{r}+6,400 \\
+6,400 \\
+11,900 \\
+6,400 \\
-1,700 \\
-8,100 \\
-34,200 \\
-Y . P .\end{array}$ \\
\hline
\end{tabular}

Nore. - + indicates tension; - indicates compression; Y. P. indicates that metal has reached its yield point.

The effect of this deformation on the transverse and longitudinal stresses in the shell is shown in Tables 8 and 9. It is seen in Table 8 that high compressive stresses were produced for a distance of over 3 inches from the junction in butt-weld tank No. 9 and that the tensile stresses in gauge lines $4 \frac{1}{2}$ inches away were much reduced in value. For the lap-weld tank No. II, the com- 
pression extends to less than 3 inches from the junction. This is doubtless due to the fact that there was a double thickness of metal to reduce the effect of the compressive forces. This would indicate that these abnormal stresses can be reduced by the introduction of extra metal for reenforcement at these junctions.

TABLE 8.-Transverse Stresses in Cylindricai Shell Near Junction with Spherical End.

\begin{tabular}{|c|c|c|c|c|c|c|c|c|}
\hline \multirow{4}{*}{ Hyerrostatic pressure. } & \multicolumn{8}{|c|}{ Apparent stress $S_{\mathrm{T}}^{\prime}=e_{\mathrm{T}} E$. } \\
\hline & \multicolumn{8}{|c|}{ Distance from junction (inches). } \\
\hline & \multicolumn{4}{|c|}{ Butt-Weld tank No. 9.} & \multicolumn{4}{|c|}{ Lap-weld tank No. 11.} \\
\hline & $1 \frac{1}{2}$ & 3 & $4 \frac{1}{2}$ & 7 & 0 & $\frac{1}{2}$ & 3 & $4 \frac{1}{2}$ \\
\hline
\end{tabular}

Pounds qer square inch.

\begin{tabular}{|c|c|c|c|c|c|c|c|c|}
\hline 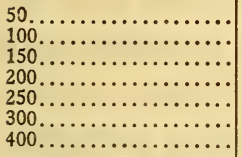 & $\begin{array}{l}-12,600 \\
-20,300 \\
-37,300 \\
-Y . P . \\
-Y . P . \\
-Y . P . \\
-Y . P .\end{array}$ & $\begin{array}{l}-1,500 \\
-2,200 \\
-16,300 \\
-29,600 \\
-Y . P . \\
-Y . P . \\
-Y . P .\end{array}$ & $\begin{array}{r}+700 \\
+4,400 \\
+5,400 \\
+8,300 \\
+8,000 \\
+9,100 \\
+13,400\end{array}$ & $\begin{array}{l}+2,100 \\
+8,000 \\
+13,200 \\
+18,500 \\
+23,400 \\
+31,100 \\
+Y . P .\end{array}$ & $\begin{array}{l}-5,400 \\
-13,100 \\
-31,100 \\
-Y . P \\
-Y . P \\
-Y . P \\
-Y . P .\end{array}$ & $\begin{array}{l}-6,200 \\
-16,100 \\
-22,500 \\
-Y . P . \\
-Y . P . \\
-Y . P . \\
-Y . P .\end{array}$ & $\begin{array}{l}+2,100 \\
+6,500 \\
+9,800 \\
+13,700 \\
+15,200 \\
+ \text { Y.P. } \\
+ \text { Y.P. }\end{array}$ & $\begin{array}{l}+3,300 \\
+7,600 \\
+13,100 \\
+18,700 \\
+24,300 \\
+29,000 \\
+ \text { Y.P. }\end{array}$ \\
\hline
\end{tabular}

NOTE. - + indicates tension; - indicates compression; Y. P. indicates that the metal has reached its yield point.

These high compressive stresses were accompanied by correspondingly high tensile stresses in a longitudinal direction. The pressure which caused the 8-inch longitudinal gauge lines near the end of the shell to reach the yield point in tension are given in Table $9(a)$. Table $9(b)$ shows these values for the radial gauge lines near the periphery of the spherical end.

TABLE 9.--Pressure Which Caused Gauge Iines Near Junction of End and Shell to Reach the Yield Point in Tension.

(a) 8-INCH LONGITUDINAL GAUGE LINES NEAR END OF CYLINDRICAL SHELL.

\begin{tabular}{|c|c|c|c|c|c|}
\hline \multicolumn{2}{|l|}{ Tank No. 9.} & \multicolumn{2}{|c|}{ Tank INo. 10.} & \multicolumn{2}{|c|}{ Tank No. 11.} \\
\hline Gauge line. & Pressure. & Gauge line. & Pressure. & Gauge line. & Pressure. \\
\hline 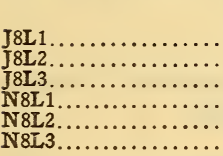 & \begin{tabular}{|r|} 
Lbs./in. ${ }^{2}$ \\
200 \\
200 \\
250 \\
200 \\
250 \\
300
\end{tabular} & $\begin{array}{l}\text { H8L1 } \ldots \ldots \ldots \ldots \\
\text { H8L } 2 \ldots \ldots \ldots \ldots \\
\text { H8L } 3 \ldots \ldots \ldots \ldots \\
\text { N8L1 } \ldots \ldots \ldots \ldots \ldots \\
\text { N8L } 2 \ldots \ldots \ldots \ldots \\
\text { N8L } 3 \ldots \ldots \ldots \ldots\end{array}$ & $\begin{array}{r}\text { Ibs./in.2 } \\
1250+(33,300) \\
250+(31,200) \\
250+(26,500) \\
250 \\
250+(28,600) \\
250\end{array}$ & 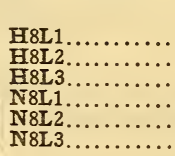 & $\begin{array}{r}\text { Lbs./in. }{ }^{2} \\
300 \\
\ldots \ldots \\
300 \\
300 \\
250 \\
300\end{array}$ \\
\hline
\end{tabular}

(b) 2-INCH RADIAL GAUGE LINES NEAR PERIPHERY OF SPHERICAL END.

\begin{tabular}{|c|c|c|c|c|c|}
\hline 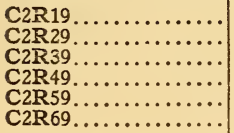 & $\begin{array}{l}200 \\
150 \\
200 \\
200 \\
200 \\
200\end{array}$ & 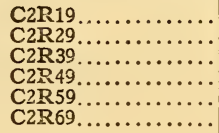 & $\begin{array}{l}200 \\
200 \\
200 \\
200 \\
150 \\
150\end{array}$ & 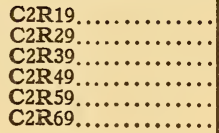 & $\begin{array}{l}200 \\
250 \\
250 \\
200 \\
200 \\
200\end{array}$ \\
\hline
\end{tabular}

1 Did not reach the yield point with maximum pressure applied. The numbers in parentheses indicate the apparent stress $\left(S_{\mathrm{L}}^{\prime}=e_{\mathrm{L}} E\right)$ Ibs./in. ${ }^{2}$ at the maximum pressure. 


\section{IMPACT TESTS.}

The results of the impact tests were indeterminate. This test was applied only to the two tanks which withstood a pressure of $300 \mathrm{lbs}$./in. ${ }^{2}$, and neither tank failed under the impact test. For tanks of this size this test is evidently of little value for detecting poor adhesion or unsatisfactory welding.

\section{FAILURE OF THE TANKS UNDER HYDROSTATIC PRESSURE.}

The results of the hydrostatic tests of the tanks proved rather unsatisfactory as a means of comparison of the relative strengths of the different types of construction. Due to secondary failure, such as leaks around the fittings, the possible strength of the tanks was not reached.

Table Io summarizes the data concerning the strength of the tanks under pressure. Examination of these data shows that all the tanks except one leaked under $50 \mathrm{lbs} . /$ in. $^{2}$ air pressure and that, with the exception of the riveted tank, these leaks were in the welds around the fittings. It is probable that higher strengths would have been obtained if the fittings had been welded to the shell both outside and inside.

Tanks Nos. Io and 12 failed at about design pressure or less. There is little doubt that their failure was due to poor welding and calking. The importance of complete and careful welding about fittings will be readily perceived when it is recognized that the holes cut for such fittings are points of discontinuity in stress distribution, and that as a result of such interference with the stresses in the plate excessively high stresses are developed in the material bordering the opening. ${ }^{3}$

It will be remembered that excessively high stresses and deformations were developed at the juncture of the end and shell, and these were high enough to cause failure irrespective of workmanship. This deformation caused leaks which resulted in the failure of the riveted tank No. I2 at low pressure.

${ }^{3}$ See Coker, E. G., and Satake, Y., "Effect of holes on stress distribution," Institution of Engineers and Ship Builders, Scotland, Nov. I8, I919; also Engineering, 109, p. 259, Feb. 20, I920. 
TABLE 10.-Summary of Results of Hydrostatic Tests.

\begin{tabular}{|c|c|c|c|c|}
\hline \multirow[b]{2}{*}{ Tank. } & \multirow[b]{2}{*}{$\begin{array}{l}\text { Location of leaks at } 50 \\
\text { lbs./in. }{ }^{2} \text { air pressure. }\end{array}$} & \multirow[b]{2}{*}{$\begin{array}{l}\text { Hydrostatic pressure to } \\
\text { cause first leak (lbs./in. }{ }^{2} \text { ). }\end{array}$} & \multicolumn{2}{|r|}{ Failure. } \\
\hline & & & $\begin{array}{c}\text { Maxi- } \\
\text { mum } \\
\text { hydro- } \\
\text { static } \\
\text { pressure } \\
\text { (lbs./in. } .^{2} \text {. }\end{array}$ & Location. \\
\hline $\begin{array}{l}\text { No. 9, butt } \\
\text { weld. }\end{array}$ & $\begin{array}{l}4 \text { leaks on center transverse } \\
\text { seam, calked; large leak } \\
\text { in } 2 \text {-inch pipe flange weld, } \\
\text { calked. }\end{array}$ & $\begin{array}{l}\text { 100; leak in 2-inch pipe } \\
\text { flange weld, calked ; } \\
\text { small leak at bottom of } \\
\text { tank at transverse weld, } \\
\text { at end of tank, calked. }\end{array}$ & 1460 & $\begin{array}{l}\text { Weld around 2- } \\
\text { inch pipe outlet. }\end{array}$ \\
\hline $\begin{array}{l}\text { No. 11, lap } \\
\text { weld. }\end{array}$ & $\begin{array}{l}\text { Leak in 4-inch pipe flange } \\
\text { weld, calked; leak in } \\
\text { 2-inch pipe flange weld, } \\
\text { calked; leak at the } \\
\text { scarfing at the end of } \\
\text { longitudinal weld at end } \\
\text { of the tank, calked. }\end{array}$ & $\begin{array}{l}\text { 20c; leak in weld around } \\
4 \text { and 2-inch pipe outlet, } \\
\text { and a round manhole, } \\
\text { calked; two leaks in end } \\
\text { transverse weld, calked. }\end{array}$ & 475 & $\begin{array}{l}\text { Weld around 4- } \\
\text { inch pipe outlet } \\
\text { and manhole. }\end{array}$ \\
\hline $\begin{array}{l}\text { No. } 10 \text {, butt } \\
\text { weld. }\end{array}$ & No leaks..... & $\begin{array}{l}\text { 150; small leak in center } \\
\text { transverse seam, calked } \\
\text { held to } 250 \text {-pound pressure. }\end{array}$ & 265 & $\begin{array}{l}\text { End transverse } \\
\text { weld. }\end{array}$ \\
\hline $\begin{array}{l}\text { No. } 12 \text {, riveted } \\
\text { tank. }\end{array}$ & $\begin{array}{l}3 \text { large leaks at end trans- } \\
\text { verse seams, calked. }\end{array}$ & $\begin{array}{l}100 \text {; numerous leaks at end } \\
\text { transverse joints. }\end{array}$ & 150 & $\begin{array}{l}\text { End transverse } \\
\text { riveted joints. }\end{array}$ \\
\hline
\end{tabular}

1 Tank No. 9, butt weld, was rewelded at the pipe-outlet flange. All other leaks were calked and the tank again tested. At a hydrostatic pressure of 505 pounds, the tank failed by large leaks developing at the center transverse weld.

\section{SUMMARY.}

The results of the analysis of the deformation and distribution of stress in these tanks appear to warrant the following general conclusions:

\section{DEFORMATIONS AND STRESSES.}

I. The commonly accepted theory for the design of tanks is, for all practical purposes, sufficiently accurate, provided the computed stresses are not influenced by secondary stresses.

2. For thin tanks, the measured stresses, based upon the twodimensional formula, are in close agreement with the design stresses computed by the common-pressure formulas, provided the former are not affected by secondary causes. This is borne out by the results obtained at the center of the end.

3. Secondary stresses, resulting in high stress intensity, were caused by (a) faulty design of the attachment of the spherical end to the cylindrical shell, (b) nonconformity of the shell to an accurate circular section, and (c) discontinuities in the shell for the manhole and fittings. These may produce a possibly dangerous condition if present near a welded or riveted joint or seam.

4. The stresses were increased by the presence of a seam. 


\section{MECHANICAL DETAILS AND RECOMMENDATIONS.}

I. Poor welding and calking were responsible for the premature failures of two of the tanks tested.

2. Failure of the two remaining tanks showed that the attachments were not able to withstand the high stresses caused by cutting openings in the plate. The results of these tests do not warrant preference to be given to any one of the tanks.

3. With more careful workmanship these tanks can be made, having a factor of safety of two or higher, for a working stress of r6,000 lbs./in. ${ }^{2}$ in the plate.

4. All welded tanks should be proof tested to at least their working load and leaks repaired by cutting out the defective places in the seams and rewelding. Where the failure of a high-pressure tank would have serious consequences, such tanks should be proof tested to at least twice their working pressure.

5. The ends should have a transition curve between the spherical portion and the shell or sufficient reenforcement provided to reduce the high stresses. The joint or seam uniting the end and the shell should be placed well back on the shell, outside the region of bending caused by deformation of the end under internal pressure.

WASHINGTON, May 25, I923. 